\title{
PRODUKSI BERSIH PADA HOME INDUSTRI DALAM RANGKA PENGENDALIAN PELESTARIAN LINGKUNGAN
}

\author{
Laila Farichatuz Zakiyah', ${ }^{1}$ Nadiroh $^{2}$ \\ ${ }^{1}$ Manajemen Lingkungan, Pascasarjana, UNJ, Lailafarichatzu@yahoo.co.id \\ ${ }^{2}$ Dosen Manajemen Lingkungan Pascasarjana UNJ
}

\begin{abstract}
Abstrak
Konsep produksi bersih (Cleaner Production) dicetuskan oleh United Nation Environmental Program (UNEP) pada bulan Mei 1989. UNEP menyatakan bahwa produksi bersih merupakan suatu strategi pengelolaan lingkungan yang bersifat preventif, terpadu dan diterapkan secara kontinu pada proses produksi, produk, jasa untuk meningkatkan eko-efisiensi sehingga mengurangi resiko terhadap kesehatan manusia dan lingkungan (Winardi \& Susanti,2006). Penelitian dilakukan di Marcellina Silver Jl. Raya Celuk Sukawati Gianyar Bali pada tanggal 12 Mei 2018. Teknik pengumpulan data yang digunakan dalam penelitian ini berasal dari variable-variabel penelitian yakni produksi bersih (XI) dan pelestarian lingkungan (X2). Diperoleh dengan cara memberikan angket (kuesioner) kepada sampel penelitian (pengusaha) untuk diisi jawaban sesuai dengan pernyataan yang dibuat. Industri perak Marcellina Silver telah menerapkan produksi bersih dengan cara melakukan beberapa kegiatan seperti, mematikan kran air jika tidak digunakan dan mematikan lampu saat siang hari, menggunakan kembali bahan sisa produksi untuk dijadikan barang produk jadi dan juga melakukan perawatan atau maintenance pada mesin produksi sehingga dapat melakukan produksi dengan optimal.
\end{abstract}

Kata kunci : industri rumahan, pelestarian lingkungan, produksi bersih

\begin{abstract}
The concept of cleaner production was coined by the United Nations Environmental Program (UNEP) in May 1989. UNEP states that cleaner production is a preventive, integrated and continuous environmental management strategy in the production process, products, services to improve eco efficiency so as to reduce risks to human health and the environment (Winardi \& Susanti, 2006). The study was conducted at Marcellina Silver Jl. Raya Celuk Sukawati Gianyar Bali on May 12, 2018. Data collection techniques used in this study came from research variables namely clean production (X1) and environmental preservation (X2). Obtained by giving a questionnaire (questionnaire) to the research sample (entrepreneur) to fill in the answers in accordance with the statements made. The silver industry Marcellina Silver has implemented clean production by carrying out several activities such as turning off the water faucet when not in use and turning off the lights during the day, reusing waste materials to be made into finished products and also doing maintenance on the production machine so that it can perform production optimally.
\end{abstract}

Keywords: home industry, environmental conservation, cleaner production 


\section{PENDAHULUAN}

Konsep produksi bersih (Cleaner Production) dicetuskan oleh United Nation Environmental Program (UNEP) pada bulan Mei 1989. UNEP menyatakan bahwa produksi bersih merupakan suatu strategi pengelolaan lingkungan yang bersifat preventif, terpadu dan diterapkan secara kontinu pada proses produksi, produk, jasa untuk meningkatkan ekoefisiensi sehingga mengurangi resiko terhadap kesehatan manusia dan lingkungan (Winardi \& Susanti,2006).

Menurut Indrasti dan Fausi (2009) keberhasilan atau pencapaian target pengelolaan lingkungan bukan merupakan akhir suatu upaya melainkan menjadi input bagi siklus upaya pengelolaan lingkungan berikutnya. Menurut Surna et al (2011) produksi bersih didefinisikan sebagai upaya penerapan yang kontinyu dari suatu strategi pengelolaan lingkungan yang integrative dan preventif terhadap manusia dan lingkungan. Produksi bersih juga diharapkan dapat meningkatkan efisiensi bahan baku dan meningkatkan keuntungan. Menurut Resource Effcient dan Cleaner Production (RECP) dalam murjana (2010) menjadi dasar dari tiga dimensi keberlanjutan baik secara sendirisendiri maupun secara sinergi yaitu meliputi efisiensi produksi yaitu optimalisasi penggunaan secara produktif
DOI : doi.org/10.21009/jgg.091.02

dari sumber-sumber alam (bahan baku, energi, dan air), manajemen lingkungan yaitu minimisasi dampak lingkungan dana lam melalui pengurangan limbah dan emisi serta pembangunan manusia yaitu minimisasi resiko terhadap penduduk dan komunitas dan menunjang pembangunan.

\section{METODOLOGI}

Penelitian dilakukan di Marcellina Silver Jl. Raya Celuk Sukawati Gianyar Bali pada tanggal 12 Mei 2018. Teknik pengumpulan data yang digunakan dalam penelitian ini berasal dari variable-variabel penelitian yakni produksi bersih (X1) dan pelestarian lingkungan (X2). Diperoleh dengan cara memberikan angket (kuesioner) kepada sampel penelitian (pengusaha) untuk diisi jawaban sesuai dengan pernyataan yang dibuat. Teknik pengumpulan data produksi bersih dan pelestarian lingkungan menggunakan rubik penilaian berdasarkan keadaan yang ada di industri perak. Teknik pengumpulan data variabel konsep diri menggunkan kuesioner yang berskala likert yaitu selalu, sering, kadang-kadang, jarang, dan tidak pernah.

Prosedur pelaksanaan uji coba instrument adalah (1) menentukan responden uji coba, (2) pelaksanaan uji coba, (3) analisis instrument. Proses pengembangan instrument dimulai dengan 
menentukan responden kemudian dilanjutkan dengan penyusunan instrument yang mengacu pada indikator-indikator setiap variabel, tahap berikutnya konsep instrument diperiksa oleh pembimbing, untuk dilihat kecocokan pada definisi konseptual dan kisi-kisi instrument dengan teori yang dipergunakan untuk membahas variabel yang bersangkutan, setelah instrumen disetujui diuji cobakan kepada 20 orang panelis. Uji coba instrument ini dilakukan untuk menguji validitas (keabsahan) dan reliabilitas (kehandalan) butir-butir instrument yang akan digunakan dalam penelitian. Arikunto mengemukakan untuk melihat validitas sampel dari instrument yang dikembangkan perlu dilaksanakan uji coba instrument.

Menurut singarimbun, sampel uji coba hendaknya berada diluar sampel penelitian namun keadaannya lebih kurang sama dengan sampel penelitian dengan jumlah 30-50.* Penjelasan lebih lanjut tentang definisi konseptual, definisi operasional, kisi-kisi instrument, validitas dan reliabilitas instrumen masing-masing variabel disajikan pada uraian dibawah ini. *Masri Singarimbun, dan Sofian Effendi, Metode Penelitian Survei (Jakarta: PT. Pustaka LP3S Indonesia, 1995), hh 170171.
Produksi Bersih

a) Definisi Konseptual

Secara konseptual produksi bersih adalah strategi pengelolaan lingkungan yang bersifat prefentive dan terpadu yang perlu diterapkan secara terus menerus pada proses produksi dan daur hidup produk dengan tujuan mengurangi resiko terhadap manusia dan lingkungan (UNEP,2003)

b) Definisi Operasional

Secara operasional produksi bersih merupakan salah satu paradigm baru dalam pengelolaan pencemaran lingkungan. Dalam setiap kegiatan, perilaku didorong untk menerapkan prinsip produksi bersih. Penerapan produksi bersih pada industri dapat dilakukan dengan aplikasi teknologi bersih. Penerapan teknologi bersih merupakan salah satu cara untuk meningkatkan kinerja usaha yang nantinya akan terkait dengan penilaian program PROPER (environmental performance rating) yang dilakukan oleh Kementrian Lingkungan Hidup.

c) Kisi-Kisi Instrumen

Berdasarkan uraian yang terdapat pada definisi operasional di atas maka terdapat beberapa dimensi yakni penyajian dalam bentuk tabel, 
Tabel 1. Kisi-kisi Instrumen

\begin{tabular}{|l|l|}
\hline Variable & Indikator \\
\hline Pelestarian & $\begin{array}{l}\text { Menjaga kebersihan lingkungan } \\
\text { industri }\end{array}$ \\
\cline { 2 - 3 } & $\begin{array}{l}\text { Memelihara kualitas udara, air } \\
\text { dan tanah }\end{array}$ \\
\hline Produksi Bersih & Perencanaan \\
\cline { 2 - 2 } & $\begin{array}{l}\text { Ada Standar Operating } \\
\text { Procedure (SOP) penggunaan } \\
\text { bahan baku }\end{array}$ \\
\cline { 2 - 2 } & $\begin{array}{l}\text { Merencanakan petunjuk teknis } \\
\text { produksi seusai dengan SOP }\end{array}$ \\
\cline { 2 - 2 } & Pelaksanaan \\
\cline { 2 - 3 } & $\begin{array}{l}\text { Mengolah dan menggunakan } \\
\text { kembali bahan buangan industri }\end{array}$ \\
\cline { 2 - 3 } & $\begin{array}{l}\text { Memilih dan merawat teknologi } \\
\text { yang akrab lingkungan dilokasi } \\
\text { industri }\end{array}$ \\
\cline { 2 - 3 } & $\begin{array}{l}\text { Memelihara SDA yang terdapat } \\
\text { didaerah industri }\end{array}$ \\
\cline { 2 - 3 } & $\begin{array}{l}\text { Memanfaatkan kembali bahan } \\
\text { bekas produksi }\end{array}$ \\
\hline
\end{tabular}

Industri perak Marcellina Silver telah menerapkan produksi bersih dengan cara melakukan beberapa kegiatan seperti, mematikan kran air jika tidak digunakan dan mematikan lampu saat siang hari, menggunakan kembali bahan sisa produksi untuk dijadikan barang produk jadi dan juga melakukan perawatan atau maintenance pada mesin produksi sehingga dapat melakukan produksi dengan optimal.

\section{HASIL DAN PEMBAHASAN}

Berdasarkan hasil wawancara di lapangan kepada pemilik industri perak Marcellina Silver, didapatkan hasil bahwa industri perak Marcellina Silver telah menerapkan SOP (Standard Operating Procedure) dalam proses produksi kerajinan perak namun tidak dikomunikasikan sehingga sulit untuk mengontrol standar petunjuk teknis dan industri perak Marcellina Slver tidak menggunakan bahan baku yang dilindungi serta tidak menggunakan bahan baku yang bersifat kimia secara berlebihan. 


\section{DAFTAR PUSTAKA}

Suharsimi Arikunto, Prosedur Penelitian :

Suatu Pendekatan Praktik (Jakarta :

Bina Aksara, 1987), h.136. 
